\title{
AC 2007-808: ENGINEERING MANAGEMENT, THE BODY OF KNOWLEDGE AS DEFINED BY COURSEWORK
}

\section{William Peterson, Arizona State University}

Dr. Bill Peterson is on the faculty of the Department of Technology Management at Arizona State University where he teaches Strategic Management, Project Management, and Financial Management. He is a past-chair of the Engineering Management Division of ASEE; a past-president of ASEM; a past-president and founding member of Epsilon $\mathrm{Mu}$ Eta, The Engineering Management Honor Society; and president-elect of SEMS (IIE). His research interests are the justification and introduction of new technologies as well as engineering and technology management education. Prior to returning to school for his doctorate he spent 20 years in engineering, engineering management, and general management in a wide range of industries.

\section{Jane Humble, Arizona State University}

Jane Humble holds BS and MS degrees in engineering and a PhD in business from Arizona State University. She is Associate Professor of Technology Management at Arizona State University. She has been a member of the faculty at Arizona State University for about 15 years with teaching and research interests in the areas of project management, ethical issues in technology, quality management, research techniques, and managerial decision making. Prior to and during her assignments in academia Dr. Humble has worked in aerospace, large computer systems, and electronics industries, with positions including project manager, project engineer, and preliminary design engineer. Her publications include papers in Industrial Management and Journal of Behavior and Information Technology, as well as the Proceedings of the Decision Sciences Institute, Portland International Conference on Management of Engineering and Technology (PICMET), Institute of Behavioral and Applied Management (IBAM), Association of Management, Association of Employee Policy and Procedures, and others. 


\title{
Engineering Management, the Body of Knowledge as Defined by Coursework
}

\begin{abstract}
This paper looks at what is typically involved in the EM master's degree as offered by the larger programs. The schools used in this analysis were selected based on their reported enrollments. The degree requirements are based on the information posted on the academic programs' websites. This paper attempts to quantify the body of knowledge for the discipline based on what is taught by these programs.
\end{abstract}

\section{Introduction}

Inspired in large part by the success of the Project Management Institute's certification program for project managers, several bodies are now offering exam-based certification for engineering managers. The prominent two are: Engineering Management Certification International (in association with ASME, ASCE, AIMMPE, and AIChE) and the Society of Manufacturing Engineers (in association with IIE). Both have developed a body of knowledge ${ }^{1,2}$ on which to base their examinations for certification. Academically, The Accreditation Board for Engineering and Technology (ABET) has established standards for accreditation of engineering management programs (at both the bachelor's and master's level) which imply a certain body of knowledge. ${ }^{4}$ Of the many master's programs in engineering management, only one (at the Air Force institute of Technology) ${ }^{6}$ is ABET accredited. Additionally, The American Society for Engineering Management (ASEM) certifies EM masters programs due to a limitation on ABET accreditation to only one level and the accreditation need at the bachelor's level. The ASEM certification standard implies a certain body of knowledge ${ }^{5}$. ASEM lists three programs at two schools as accredited $^{7}$.

This paper ask the question: "What is the body of knowledge incorporated into engineering management as taught by the larger engineering management programs at the master's level?" The master's degree was selected as the predominant degree in engineering management since $75 \%$ of the students in EM programs are in master's degree programs (18\% at the bachelor's degree level and 8\% at the doctor's level) according to enrollment numbers for 2004 reported by the Engineering Workforce Commission ${ }^{3}$.

\section{Methodology}

To answer this question the following steps were used:

1. The larger engineering management master's degree programs were selected as the sample. Since the Engineering Workforce Commission of the American Association of Engineering Societies complies and publishes this data annually, the most recent version available at the time this research was started was used - Fall 2004 data published in 2005. The enrollment numbers were 5693 in engineering management programs with 
4264 students at the master's level ${ }^{3}$. The largest $33 \%$ of the programs (self-reporting) were selected as the sample. These 28 programs are listed in Table 1 . These 28 schools have $75 \%$ of the reported students enrolled.

Table 1: Schools Used as Sample

\begin{tabular}{|c|l|r|}
\hline Rank & \multicolumn{1}{|c|}{ University } & Students \\
\hline 1 & George Washington University & 329 \\
\hline 2 & Old Dominion University & 242 \\
\hline 3 & Stanford University & 212 \\
\hline 4 & University of Michigan - Dearborn & 196 \\
\hline 5 & Santa Clara & 162 \\
\hline 6 & University of Kansas & 147 \\
\hline 7 & University of Missouri - Rolla & 129 \\
\hline 8 & Southern Methodist & 125 \\
\hline 9 & John Hopkins & 118 \\
\hline 10 & Drexel & 106 \\
\hline 11 & Wayne State University & 104 \\
\hline 12 & Northwestern University & 97 \\
\hline 13 & Oakland University & 96 \\
\hline 14 & California State University - Northridge & 94 \\
\hline 15 & Oklahoma State & 92 \\
\hline 16 & Air Force Institute of Technology & 91 \\
\hline 17 & Columbia University & 80 \\
\hline 18 & Florida International University & 79 \\
\hline 19 & Rose-Hulman & 79 \\
\hline 20 & Colorado School of Mines & 71 \\
\hline 21 & Washington University & 67 \\
\hline & Oregon Graduate Institute of Science and & 63 \\
\hline 22 & Technology & 65 \\
\hline 23 & Washington State & 59 \\
\hline 24 & Lawrence Technical University & 57 \\
\hline 25 & University of Minnesota - Twin Cities & \\
\hline 26 & Northeastern University & 63 \\
\hline 27 & Portland State University & 6 \\
\hline 28 & Florida Institute of Technology & 6 \\
\hline
\end{tabular}

2. Web-sites for each program were accessed in November/December, 2006 or in January 2007. Based on the data found on the websites, a table was constructed classifying each required course into topic classes based on (a) the course title and (b) a review of the catalog listing for the course in most cases. The classification was done by the author, an engineering management educator for the past 13 years with an additional 18 years as a practicing engineering manager. The classification system was not predetermined but driven by data with new topic classifications added as needed to accommodate the courses found. Only core courses were included in the tabulation. Five of the 28 programs were not included in the tabulation data due to (a) a "cafeteria" approach [e.g. - 
allowing the student to select a small number of courses from a very large list of courses], or (b) not clearing specifying a set of core courses. One of the 28 programs was not included as the only "engineering management" program found at the university was in "construction engineering management" and with a curriculum clearly directed to construction.

3. In addition to classifying the topics, a weight equal to the credit hours was assigned to each course. In some cases a portion of a set of courses (e.g. 3 of 5) were called out as the core. In these cases, the credit hours of the courses were weighted (in the example, the credit hours were adjusted to $60 \%$ of standard) based on an assumption that each course was equally likely to be taken by any student.

4. Next the credit hours were adjusted to semester hours -6 of the 28 programs were on the quarter system.

5. The next step was to weight the adjusted credit hours for each course by the enrollment in the program.

6. The sums of the calculation in step 5 were the made by topic classification. Additionally, the number of schools with at least one representative course in a classification was calculated.

\section{The Resulting Data}

Table 2 tabulates the course topics in decreasing order of student credit hours associated with this topic. The topic of management in technical organizations is the most commonly seem course. The impact of this topic is even greater when taken in conjunction with the courses on organizational behavior (rank 6). These topics were differentiated because the courses listed under the organizational behavior heading appeared to be clearly on this topic. The management in technical organization classification contains a much wider group of topics in the description (often including a healthy dose of organizational behavior) but also additional topics on management.

Table 2: Topics Ranked by Weighted Student Credit hours

\begin{tabular}{|l|r|r|}
\hline \multicolumn{1}{|c|}{ Topic } & $\begin{array}{c}\text { Weighted } \\
\text { Student } \\
\text { Credit } \\
\text { Hours }\end{array}$ & $\begin{array}{c}\text { Credit Hour } \\
\text { Rank }\end{array}$ \\
\hline Management in Technical Organization & 6876 & 1 \\
\hline Engineering Economics / Finance & 5616 & 2 \\
\hline Project Management & 4577 & 3 \\
\hline Operations Research & 3416 & 4 \\
\hline Marketing & 3410 & 5 \\
\hline Organizational Behavior & 3070 & 6 \\
\hline Production/Operations Management & 2800 & 7 \\
\hline Strategic Management & 2665 & 8 \\
\hline
\end{tabular}




\begin{tabular}{|l|r|r|}
\hline Systems Engineering & 2478 & 9 \\
\hline Managerial Accounting & 2234 & 10 \\
\hline Probability and Statistics & 1863 & 11 \\
\hline Quality & 1730 & 12 \\
\hline Managerial Finance & 1401 & 13 \\
\hline Simulations / Quantitative Methods & 1344 & 14 \\
\hline Problem Solving / Decision Making & 1129 & 15 \\
\hline Information Systems & 796 & 16 \\
\hline Managerial Economics & 665 & 17 \\
\hline Personal Development for Engineering & & \\
Managers & 588 & 18 \\
\hline Management of Product/Process Design & 588 & 19 \\
\hline Technical Communications & 562 & 20 \\
\hline Risk Analysis & 511 & 21 \\
\hline Ethic/Law & 392 & 22 \\
\hline Decision Analysis & 326 & 23 \\
\hline Statistical Quality Control & 230 & 24 \\
\hline Computer Integrated Manufacturing & 230 & 25 \\
\hline Engineering Management @ The Upper & & \\
Levels & 196 & 26 \\
\hline Software Engineering & 177 & 27 \\
\hline Environmental Policy and Sustainable & & \\
Development & 164 & 28 \\
\hline
\end{tabular}

Another classification pair needing additional comment is engineering economy and finance versus managerial finance. The first classification includes those courses which address issues such as project justification while the later classification includes the more traditional finance courses - balances sheets, raising capital, and the like.

Table three reports the same topics ranked by requirement in the program regardless of the school's size or the credit hours for the course.

Table 3: Topics Ranked by Schools Requiring

\begin{tabular}{|l|r|r|}
\hline \multicolumn{1}{|c|}{ Topic } & $\begin{array}{c}\text { Schools } \\
\text { Requiring }\end{array}$ & Rank \\
\hline Engineering Economics / Finance & 13 & 1 \\
\hline Management in Technical Organization & 12 & 2 \\
\hline Project Management & 12 & 2 \\
\hline Operations Research & 12 & 2 \\
\hline Organizational Behavior & 9 & 5 \\
\hline Managerial Accounting & 9 & 5 \\
\hline Strategic Management & 8 & 7 \\
\hline Simulations / Quantitative Methods & 8 & 7 \\
\hline Production/Operations Management & 7 & 9 \\
\hline Probability and Statistics & 7 & 9 \\
\hline
\end{tabular}




\begin{tabular}{|l|r|r|}
\hline Managerial Finance & 7 & 9 \\
\hline Marketing & 6 & 12 \\
\hline Systems Engineering & 4 & 13 \\
\hline Technical Communications & 4 & 13 \\
\hline Quality & 3 & 15 \\
\hline Managerial Economics & 3 & 15 \\
\hline Engineering Management @ The Upper & & \\
Levels & 3 & 15 \\
\hline Problem Solving / Decision Making & 2 & 18 \\
\hline Information Systems & 2 & 18 \\
\hline Risk Analysis & 2 & 18 \\
\hline Decision Analysis & 2 & 18 \\
\hline Personal Development for Engineering & & \\
Managers & 1 & 22 \\
\hline Management of Product/Process Design & 1 & 22 \\
\hline Ethic/Law & 1 & 22 \\
\hline Statistical Quality Control & 1 & 22 \\
\hline Computer Integrated Manufacturing & 1 & 22 \\
\hline Software Engineering & 1 & 22 \\
\hline Environmental Policy and Sustainable & & \\
Development & 1 & 22 \\
\hline
\end{tabular}

\section{Implications of the Results}

The above collection and classification is a first attempt at looking at how we, the academic community (since programs and curricula are approved by not only the engineering management programs but the department, the college and university), view the EM body of knowledge. It is a rough cut. Additional data collection and analysis is needed. As we all know, the devil is in the details. The course title and the catalog listing are one thing - the course content may be another. To this end the next step in this research is to attempt to refine classification of the course content. This step will be to conduct a survey in which the text used in the courses will be identified. This should more clearly identify the course content.

Having said that the data is imperfect, can any conclusions be drawn? It can be argued that the academic community puts management of money (finance/engineering economics, managerial finance, managerial accounting), projects (project management) and of people (management of technical organizations, organizational behavior) at the forefront of EM. This is closely followed by the other classical management, note management - not engineering management, areas of strategy and marketing and our industrial engineering roots $(\mathrm{OR} /$ simulation, production planning and control).

Several additional items were gleamed from this study;

1. Eight of the 28 programs had an experience requirement. This requirement was almost uniformly distributed at 2,3 , and 5 years.

2. Only one program seemed to require a thesis - the ABET accredited one. 
3. Capstone projects were common but not universal for programs without a thesis requirement.

4. The typical core was 7 courses of 3 credits each.

5. The presentation to students of both admission and degree requirements was often difficult to find and understand although, of the two admissions requirement were easier to find and generally straight forward. The degree requirements were often presented in a format requiring an unreasonable degree of familiarity to comprehend.

6. Most programs accepted both engineers and graduates from science programs especially the applied sciences - and required few prerequisite courses for admission. A calculus based statistics courses was a frequent expectation.

\section{Conclusions}

Based on the findings in Tables 3 and 4, a rough cut at the engineering management body of knowledge based on the academic programs can be identified. Four topics are the top four in each list: (a) Engineering Economics/Financial Management, (b) Management in Technical Organizations, (c) Project Management, and (d) Operations Research. Two additional topics are common to the five to eight positions in both lists: (e) Strategic Management and (f) Organizational Behavior.

This investigation has been encouraging.

$\circ$ There does seem to be common threads running through engineering management programs.

$\circ$ There is some level of congruence between the individual certification programs and the engineering management master's degree programs.

$\circ$ The flexibility observed in most programs allows the student to investigate areas in the certification which may not be in the programs core. An example is marketing - it is in only six of the programs as a core course but is fifth for weighted student credit hour. Students seeking certification can easily add this to most programs as an elective.

- The amount of "management" in the programs was a pleasant surprise. The "conventional wisdom" going into this study was that this area was a weakness for engineers and by extension for engineering managers. This probably is the same problem seen in surveys which discuss shortfall in engineering skills but do not limit the practitioners discussed to degreed engineers. The management of the human element seems to be a key thrust in the academic programs and should be used as a major point in marketing them.

\section{Bibliography}

1. Society of Manufacturing Engineers:, Certified Engineering Manager (CEM), Body of Knowledge; SME, 2002

2. Engineering Management Certification International; 2006 A Guide to the Engineering Management Certification Body of Knowledge (EMC-BOK Guide); EMCI, 2006

3. Engineering Workforce Commission, Engineering and Technology Enrollments, Fall 2004, AAES EWC, 2005

4. Engineering Accreditation Commission, ABET, Inc., "Criteria for Accrediting Engineering Programs", October 28,2006 
5. American Society for Engineering Management, “American Society for Engineering Management Engineering Management Masters Program Certification Academic Standards", October 20, 2003

6. ABET, http://www.abet.org/schoolareaeac.asp

7. ASEM, http://www.asem.org/members/certific.html 